\title{
Transcriptome analysis of Yersinia pestis in human plasma: an approach for discovering bacterial genes involved in septicaemic plague
}

\author{
Sylvie Chauvaux, ${ }^{1}$ Marie-Laure Rosso, ${ }^{2}$ Lionel Frangeul, ${ }^{3}$ Céline Lacroix, ${ }^{4}$ \\ Laurent Labarre, ${ }^{5}$ Angèle Schiavo, ${ }^{4}$ Michaël Marceau, ${ }^{2}$ \\ Marie-Agnès Dillies, ${ }^{4}$ Jeannine Foulon, ${ }^{1}$ Jean-Yves Coppée, ${ }^{4}$ \\ Claudine Médigue, ${ }^{5}$ Michel Simonet ${ }^{2}$ and Elisabeth Carniel $^{1}$ \\ ${ }^{1}$ Yersinia Research Unit, Institut Pasteur, 28 rue du Dr. Roux, F-75724 Paris cedex 15, France \\ ${ }^{2}$ Institut Pasteur de Lille, Lille, France \\ ${ }^{3}$ Plate-Forme 4, Institut Pasteur, Paris, France \\ ${ }^{4}$ Plate-Forme 2, Institut Pasteur, Paris, France \\ ${ }^{5}$ Génoscope, Evry, France
}

Correspondence

Sylvie Chauvaux chauvaux@pasteur.fr

Received 22 January 2007

Revised 14 May 2007

Accepted 14 May 2007

\section{INTRODUCTION}

Yersinia pestis is a highly infectious, Gram-negative bacterium that causes plague. The pathogen belongs to the family Enterobacteriaceae and is subdivided into three classic biovars [Antiqua, Medievalis and Orientalis (Devignat, 1951)] and one additional biovar [designated

\section{Abbreviation: QRT-PCR, quantitative real-time PCR.}

A supplementary figure showing QRT-PCR confirmation of transcriptome results, and four supplementary tables listing the fold-changes due to medium, temperature and growth phase, and the 30 most highly expressed $Y$. pestis chromosomal genes in human plasma, are available with the online version of this paper.

The array data discussed in this publication have been deposited in the Genoscript database (http://genoscript.pasteur.fr) and are accessible as experiment 'Human plasma Y. Pestis'.
Microtus or Pestoides (Zhou et al., 2004)] which is thought to represent the ancestral $Y$. pestis branch (Achtman et al., 2004). Although plague is primarily a zoonotic disease, humans are also extremely susceptible to infection, with recent reports of about 2000 cases per year (http://www. who.int/mediacentre/factsheets/fs267/en/). Three main clinical forms are designated according to the route of infection (Dennis et al., 1999). Bubonic plague is the most common form and results from the bite of an infected flea. Pneumonic plague is less common but is considered to be highly contagious, since it is transmitted from human to human by aerosols; the incubation period is very short (1-3 days) and death ensues almost invariably if appropriate antibiotic therapy is not initiated within $18-24 \mathrm{~h}$ of disease onset. Septicaemic plague is the least frequent and most fulminating, fatal form of plague. It results from direct penetration of 
the bacterium into the bloodstream through skin lesions or via the conjunctiva. In all three forms, the terminal phase of plague is characterized by bacterial dissemination into the bloodstream, leading to rapid death of the host.

The bacterial factors required during the septicaemic phase of plague are largely unknown. Certain virulence factors identified in $Y$. pestis appear to be more important in the initial phase of the infection (enabling the bacterium to disseminate into its host) than in the septicaemic phase. This is the case for the Pla protease, a cell-surface plasminogen activator which is essential for the development of bubonic plague via peripheral routes of infection, but which has little impact on septicaemic plague (i.e. when the bacteria are delivered intravenously or via a fleabite directly into the bloodstream) (Sebbane et al., 2006a; Sodeinde et al., 1992). Similarly, even though the yersiniabactin-dependent iron-uptake system is required for development of a fatal $Y$. pestis infection when bacteria are injected subcutaneously, the system is completely nonessential following intravenous infection (Bearden et al., 1997; Bearden \& Perry, 1999; Une \& Brubaker, 1984). A few known $Y$. pestis virulence factors have been shown to be required for development of the disease when bacteria are directly inoculated into the bloodstream. This is true for the pCD1 plasmid, a major virulence factor that delivers toxic proteins into host cells and which is essential for triggering plague when the bacteria are delivered peripherally or directly into the bloodstream (Brubaker, 2000). Likewise, the Yfe iron-acquisition system seems to play a key role after either subcutaneous or intravenous infection in mice (Bearden \& Perry, 1999). Lastly, the PsaA fimbria (an antiphagocytic factor also known as $\mathrm{pH} 6$ antigen) is involved in plague disease when bacteria are injected intravenously (Lindler et al., 1990).

Since little is known about the $Y$. pestis factors that are specifically turned on during the septicaemic phase of the disease, we decided to analyse the overall transcriptional response of $Y$. pestis during growth in conditions resembling plague septicaemia. For this purpose, we prepared whole-genome macroarrays of fully virulent $Y$. pestis CO92 biovar Orientalis (Parkhill et al., 2001). This strain was grown in human plasma or Luria-Bertani (LB) medium and at either 37 or $28{ }^{\circ} \mathrm{C}$. Since the physiological status of $Y$. pestis in human blood is not known, transcription profiling of both mid-exponential and stationary-phase bacteria was performed. Hence, we carried out transcriptome analysis under a total of eight different growth conditions (examining three variables: medium, temperature and growth phase). We first identified genes induced in human plasma and then focused on those specifically induced at $37^{\circ} \mathrm{C}$ or showing growth-phase-dependent transcriptional regulation.

\section{METHODS}

Preparation of whole-genome macroarrays. Pairs of specific primers were designed for each of the 4221 ORFs present on the $Y$. pestis CO92 chromosome and the three plasmids, using the CAATBox and Primer3 software packages (Frangeul et al., 2004; Parkhill et al., 2001). Primers were chosen in order to amplify 400-500 bp fragments with a melting temperature of $55{ }^{\circ} \mathrm{C}$. Briefly, the CAATBox software automatically selected the part of a gene which presented the least similarity to the rest of the genome and then checked that the primer pairs (provided by Primer3 software) were unlikely to produce non-specific amplifications. Next, to ensure specificity, the theoretical PCR products were compared with the genome by BLASTN. A total of 4126 primer pairs were designed and synthesized. Amplification reactions were performed by Eurogentec and were successful for $97 \%$ of primer pairs. PCR products were spotted on nylon membranes (Genetix) previously soaked in $10 \mathrm{mM}$ Tris, $1 \mathrm{mM}$ EDTA, pH 7.6, using a QPix robot (Genetix). Genomic DNA from Y. pestis CO92 and a range of amounts (10-100 ng) of luciferase DNA (Promega) were spotted as positive controls. Salmon sperm DNA and DNA-free samples were spotted as negative controls. Membrane-spotted DNA was denatured for $15 \min$ in $0.5 \mathrm{M} \mathrm{NaOH}$, $1.5 \mathrm{M} \mathrm{NaCl}$, washed three times with water and then dried on Whatman paper. Successful spotting of DNA samples on nylon membranes was ensured by performing hybridization with ${ }^{33} \mathrm{P}$ labelled genomic DNA from $Y$. pestis CO92. Membranes were stored at $-20{ }^{\circ} \mathrm{C}$ until use.

Bacterial strain and media. The fully virulent Yersinia pestis strain CO92 (biovar Orientalis) was grown in either LB medium or human plasma. A pool of 56 human plasma samples (Etablissement Français du Sang) was aliquoted and conserved at $-20{ }^{\circ} \mathrm{C}$. Before use, human plasma was decomplemented by incubation at $56{ }^{\circ} \mathrm{C}$ for $30 \mathrm{~min}$ and was then partially clarified by centrifugation at $5000 \mathrm{~g}$ for $10 \mathrm{~min}$.

Bacterial growth. For each experiment, Y. pestis CO92 was taken from the $-80{ }^{\circ} \mathrm{C}$ stock, streaked on $\mathrm{LB}$ plates containing $20 \mu \mathrm{g}$ haemin $\mathrm{ml}^{-1}$ and incubated for $48 \mathrm{~h}$ at $28{ }^{\circ} \mathrm{C}$. An inoculum was prepared by suspending bacteria from the plate into $0.15 \mathrm{M} \mathrm{NaCl}$, followed by dilution to $\mathrm{OD}_{600} 0.02$ in $40 \mathrm{ml}\left(2 \times 10^{7}\right.$ bacteria $\left.\mathrm{ml}^{-1}\right)$ culture medium pre-heated to 37 or $28{ }^{\circ} \mathrm{C}$. Cultures were performed at either 28 or $37{ }^{\circ} \mathrm{C}$ with shaking. Growth was monitored by measuring $\mathrm{OD}_{600}$. In view of the high optical density of human plasma at $600 \mathrm{~nm}$, samples were diluted twofold in $0.15 \mathrm{M} \mathrm{NaCl}$ prior to reading the $\mathrm{OD}_{600}$. The $\mathrm{OD}_{600}$ values of infected plasma were determined by subtracting the $\mathrm{OD}_{600}$ value of uninfected plasma.

Isolation of total RNA. Either $10 \mathrm{ml} \mathrm{Y}$. pestis grown in LB or $40 \mathrm{ml}$ $Y$. pestis grown in human plasma was centrifuged at $6000 \mathrm{~g}$ for $5 \mathrm{~min}$ at $4{ }^{\circ} \mathrm{C}$. Pellets were promptly suspended in $1 \mathrm{ml}$ RNAwiz (Ambion) and immediately stored at $-80{ }^{\circ} \mathrm{C}$. The defrosted lysate was treated with $200 \mu \mathrm{l}$ chloroform, vigorously shaken for $20 \mathrm{~s}$ and incubated at room temperature for $10 \mathrm{~min}$. The aqueous phase was recovered after centrifugation at $4{ }^{\circ} \mathrm{C}(12000 \mathrm{~g}$ for $10 \mathrm{~min})$ and diluted with $450 \mu \mathrm{l}$ $\mathrm{H}_{2} \mathrm{O}$. RNA was precipitated by addition of $18 \mu \mathrm{l}$ nuclease-free glycogen $\left(5 \mathrm{mg} \mathrm{ml}^{-1}\right.$; Ambion) and $900 \mu \mathrm{l}$ 2-propanol, then pelleted by centrifugation at $12000 \mathrm{~g}$ for $30 \mathrm{~min}$ at $4{ }^{\circ} \mathrm{C}$. Pellets were rinsed with cold $70 \%$ ethanol, dried and suspended in $50 \mu \mathrm{l}$ water. DNA was removed from the RNA samples by adding $4 \mathrm{U}$ DNase, as described in the instructions for use of the DNA-free kit (Ambion). Total RNA was quantified by $A_{260}$. RNA purity and quality were checked using an Agilent 2100 bioanalyser. Purified RNA samples were aliquoted and stored at $-80{ }^{\circ} \mathrm{C}$ until use.

Probe synthesis. Radioactive cDNA probes were prepared from RNA by incorporation of $\left[{ }^{33} \mathrm{P}\right] \mathrm{dCTP}$ during first-strand cDNA synthesis with reverse transcriptase. For all experiments, the same mix of Yersinia-specific reverse primers $(0.1 \mathrm{pM})$ containing $0.1 \mathrm{pM}$ luciferase primer (Eurogentec) was used. Labelling was performed in a final volume of $45 \mu \mathrm{l}$ containing $10 \mu \mathrm{g}$ RNA, $0.5 \mathrm{ng}$ luciferase RNA (Promega), 0.35 pmol Yersinia-specific primers, $9 \mu \mathrm{l} 4 \times$ incubation 
buffer (Roche), $10 \mathrm{mmol}$ dATP, $10 \mathrm{mmol}$ dTTP, $10 \mathrm{mmol}$ dGTP, $0.1 \mathrm{mmol}$ dCTP, $50 \mu \mathrm{Ci}(1.85 \mathrm{MBq}) \quad\left[\alpha_{-}{ }^{33} \mathrm{P}\right] \mathrm{dCTP}$ (Amersham Biosciences) and $50 \mathrm{U}$ AMV reverse transcriptase (Roche). In the first step, primer hybridization was performed using a $22 \mu$ mixture of total $Y$. pestis RNA, luciferase RNA and the primers. After incubation at $90{ }^{\circ} \mathrm{C}$ for $2 \mathrm{~min}$, the heating block was placed on the bench until the temperature dropped to $42{ }^{\circ} \mathrm{C}$. In the second step, labelling was performed by addition of dNTPs, reverse transcriptase, $\left[{ }^{33} \mathrm{P}\right] \mathrm{dCTP}$ and reverse transcriptase buffer, followed by incubation at $42{ }^{\circ} \mathrm{C}$ for $3 \mathrm{~h}$. Unincorporated nucleotides were removed from the labelled cDNA by using the DyeEx 2.0 spin kit (Qiagen).

Macroarray hybridization. Membranes were hybridized in a random order so as to avoid artefacts due to technical variations encountered while performing the series of 24 hybridizations. Macroarrays were soaked in $2 \times$ SSPE buffer $(1 \times$ SSPE is $0.18 \mathrm{M}$ $\mathrm{NaCl}, 10 \mathrm{mM} \mathrm{NaH} \mathrm{PO}_{4}, 1 \mathrm{mM}$ EDTA, $\mathrm{pH}$ 7.7) and pre-hybridized for $1 \mathrm{~h}$ in the hybridization solution $(5 \times$ SSPE, $2 \%$ SDS, $1 \times$ Denhardt's reagent, $0.1 \mathrm{mg} \mathrm{ml}^{-1}$ salmon sperm DNA) at $65{ }^{\circ} \mathrm{C}$ in roller bottles. Hybridization with the entire, spin-purified, denatured cDNA probe sample was carried out for $20 \mathrm{~h}$ at $65{ }^{\circ} \mathrm{C}$ in $5 \mathrm{ml}$ fresh hybridization solution. Membranes were washed three times in washing buffer $(0.5 \times \mathrm{SSPE}, 0.2 \%$ SDS $)$ at room temperature for $3 \mathrm{~min}$, and three times with pre-heated washing buffer at $65{ }^{\circ} \mathrm{C}$ for $20 \mathrm{~min}$. Macroarrays were sealed in $25 \mu \mathrm{m}$-thick plastic sheets and then exposed to a phosphor screen (Molecular Dynamics) for $20 \mathrm{~h}$. Membranes were scanned using the STORM 860 phosphorimager (Amersham Biosciences).

Quantitative real-time PCR (QRT-PCR). cDNA was synthesized using $1 \mu \mathrm{g}$ total RNA and the Transcriptor First Strand cDNA Synthesis kit (Roche). Subsequently, real-time PCR was conducted using the LightCycler 2.0 System (Roche) according to the manufacturer's instructions. Fluorescent PCR products were generated from cDNA using the LightCycler FastStart DNA Master ${ }^{\text {PLUS }}$ SYBR Green I kit (Roche) and specific primers for each gene which were originally designed for macroarray preparation. Relative quantification was determined using YPO3356 ( $n l p D$ gene) as a standard, and was corrected using the PCR efficiency of each primer set.

Data analysis. ArrayVision software (Imaging Research) was used to quantify hybridization intensities. The intensity data were logtransformed and normalized using a simple median normalization method. Next, an ANOVA was performed first on the whole dataset and then independently for each gene, with the three variables (medium, temperature and growth phase) as fixed effects. All statistical analyses were carried out using the SAS software (SAS Institute). Three $P$ values were calculated per gene. Since the $P$ value calculation is based on a null hypothesis that states that differential expression is not genuine, low $P$ values indicate that the difference in expression is unlikely to have occurred by chance, whereas high $P$ values indicate that the differential expression is likely to be false. In other words, low $P$ values correspond to specific up- and downregulation, whereas high $P$ values correspond to an absence of differential expression. Transcriptional regulation and constitutive expression were considered to be statistically significant when the $P$ value was below 0.05 and above 0.5 , respectively.

\section{RESULTS AND DISCUSSION}

\section{Experimental design}

In order to identify $Y$. pestis genes which are likely to be specifically induced during the septicaemic phase of infection in humans, we performed comparative expression profiling of strain CO92 grown in human plasma or in the rich artificial medium LB. Human plasma and LB cultures were carried out either at the host temperature $\left(37{ }^{\circ} \mathrm{C}\right)$ or at the optimal in vitro growth temperature for Yersinia $\left(28{ }^{\circ} \mathrm{C}\right)$. Since the physiological status of $Y$. pestis during septicaemia is not known, bacteria were harvested during both the exponential phase ( $6 \mathrm{~h}$ of incubation) and the stationary phase ( $24 \mathrm{~h}$ of incubation). Therefore, eight growth conditions in all, including three variables (medium, temperature and growth phase), were studied. For each growth condition, three different mRNA preparations from independent cultures were used for cDNA synthesis and subsequent macroarray hybridization.

\section{Growth of $Y$. pestis in human plasma}

In a preliminary test, viable bacterial counts and $\mathrm{OD}_{600}$ measurements were performed in parallel in order to evaluate $Y$. pestis growth in human plasma. Since both datasets gave similar results, bacterial growth was subsequently monitored using $\mathrm{OD}_{600}$ measurements only. Given that maximal reproducibility between biological replicates is needed for reliable transcriptome analysis, Y. pestis culture conditions in human plasma were precisely set up. Growth of strain CO92 in human plasma batch cultures was compared before and after decomplementation. Prior to decomplementation, $Y$. pestis was able to multiply in human plasma, confirming that this pathogen is resistant to the bactericidal effect of complement (Porat et al., 1995; Sodeinde et al., 1992). However, the growth was characterized by high inter-experiment variation in the duration of the lag phase. When human plasma was decomplemented at $56{ }^{\circ} \mathrm{C}$ for $30 \mathrm{~min}$, a short, reproducible lag phase (followed by reproducible growth curves with typical exponential and stationary phases) was obtained. Hence, human plasma was always decomplemented before use in $Y$. pestis batch cultures.

Growth curves of $Y$. pestis in decomplemented human plasma or LB were compared at 28 and $37{ }^{\circ} \mathrm{C}$. As has been previously established (Brubaker, 2000), Y. pestis grew slightly more slowly in LB at $37{ }^{\circ} \mathrm{C}$ than at $28{ }^{\circ} \mathrm{C}$ (doubling time $1 \mathrm{~h} 55 \mathrm{~min}$ and $1 \mathrm{~h} 23 \mathrm{~min}$ at 37 and $28^{\circ} \mathrm{C}$ respectively), reflecting physiological changes that occur between room and host temperatures. However, in decomplemented human plasma, $Y$. pestis grew notably faster at $37{ }^{\circ} \mathrm{C}$ than at $28{ }^{\circ} \mathrm{C}$ (doubling time of $1 \mathrm{~h} 42 \mathrm{~min}$ and $3 \mathrm{~h} 8 \mathrm{~min}$ at 37 and $28{ }^{\circ} \mathrm{C}$, respectively). This suggests that under in vivo conditions, the complex network of temperature regulation might differ from that identified in vitro.

\section{Macroarray analysis}

An overall analysis of variance indicated that growth phase was the factor that introduced the most variation. The variance due to growth phase was 20 -fold higher than that 
due to the medium and sixfold higher than that due to temperature. This result is consistent with the tremendous changes in gene expression that reflect physiological adaptation when moving from the exponential phase into the stationary phase. More genes were regulated by the medium (715) than by temperature (461), whereas the variance due to the medium was at least threefold lower than that due to temperature. These results suggest that the medium regulates more genes than does temperature, but that it causes weaker transcriptional changes per gene.

A total of 1615 genes were found to be significantly up- or downregulated by at least one biological factor. Transcriptional fold-changes were calculated from pairwise comparisons of the conditions (human plasma vs LB; 37 vs $28{ }^{\circ} \mathrm{C}$; mid-exponential phase vs stationary phase) using normalized intensities and are provided as supplementary data (see Supplementary Tables S1, S2 and S3, respectively, available with the online version of this paper). In order to validate the macroarray results, real-time PCR quantifications were performed on a subset of genes which exhibited differential transcription under specific conditions. As shown in Supplementary Fig. S1, both methods showed similar up- and downregulation of the genes studied.

Most of the genes (1124 out of 1615) were affected by only one factor: 344 by the medium, 216 by temperature and 564 by growth phase. A fair number of genes (420) were regulated by two factors: 58 by the medium and temperature, 245 by the medium and growth phase, and 117 by temperature and growth phase. Very few genes (71) were regulated by all three factors.

\section{Genes which are transcriptionally induced in human plasma}

Of the 315 genes induced in human plasma, a large number encode proteins of unknown (120) or miscellaneous (73) function (Fig. 1). The next most numerous class corresponds to genes encoding proteins involved in iron metabolism (42 genes). Forty genes are involved in the synthesis of eleven putative inorganic iron or haem transport systems (Table 1), and two genes ( $b f r$ and $b f d$ ) are involved in iron storage. This is consistent with the low-iron environment encountered in plasma. Indeed, blood contains $<10^{-18} \mathrm{M}$ extracellular free iron, which is far below the concentration necessary for bacterial growth (at least $10^{-8} \mathrm{M}$; Stanier et al., 1986). Hence, bacterial survival and multiplication in such a low-iron milieu depend on the expression of iron uptake systems. Siderophores are sophisticated, high-affinity iron chelators which can capture iron molecules bound to host proteins and deliver them to the bacterium. Once inside the bacterial cell, the iron is removed from the complex and used in various metabolic pathways. In Y. pestis, most of the genes involved in synthesis of the yersiniabactin siderophore (Ybt) displayed transcriptional induction in human plasma and at $37{ }^{\circ} \mathrm{C}$ (Table 1), indicative of a role for yersiniabactin in the septicaemic phase of plague in humans. Interestingly, transcription of $y b t A$ (which encodes the AraC-like transcriptional activator of most $y b t$ genes) was induced during the stationary phase (Table 1). This suggests that a signal for yersiniabactin synthesis is specifically produced during this growth phase. The ExbBD and TonB proteins form an innermembrane complex which is involved in importing essential micronutrients across the outer membrane. Transcription of exbBD genes was induced in human plasma, and ton $B$ transcription was upregulated both in human plasma and at $37^{\circ} \mathrm{C}$, the same transcriptional profile as that of the $y b t$ genes. This matches the absolute requirement for TonB for transport of the ironyersiniabactin complex into Y. pestis (Perry et al., 2003). The $Y$. pestis chromosome bears a gene cluster which potentially encodes a second siderophore, named Ysu. Transcription of several $y s u$ genes was induced in human plasma (Table 1), suggesting that the Ysu siderophore is

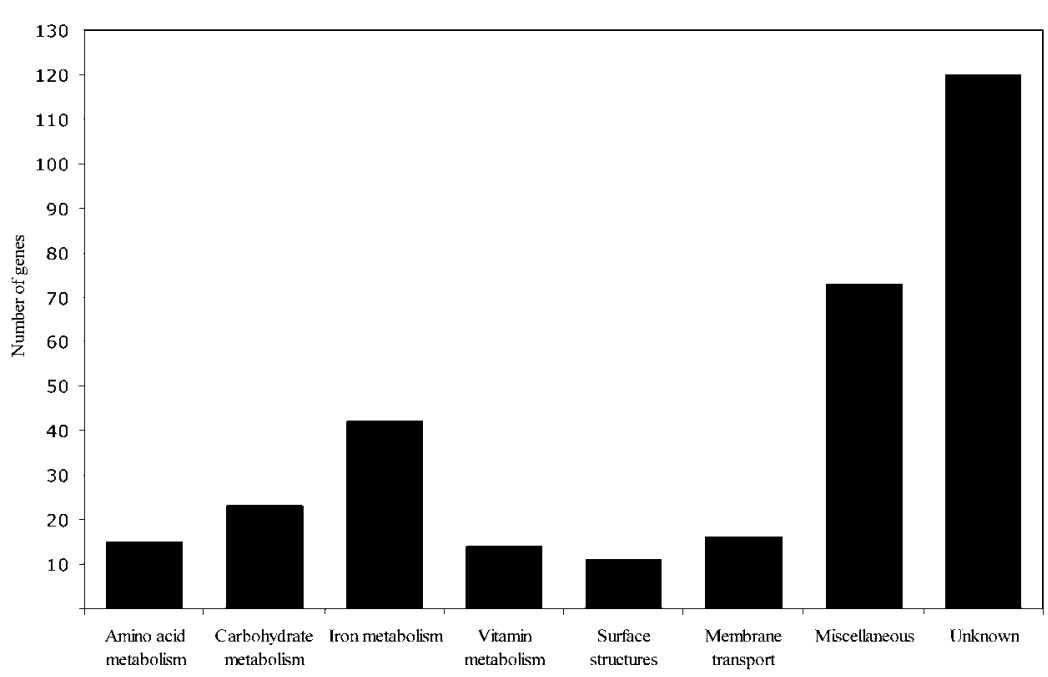

Fig. 1. Number of human plasma-induced genes per functional class, as defined in the $Y$. pestis CO92 genome annotation. 
Table 1. Genes involved in iron- and haem-uptake systems, and which are significantly regulated by one of the three factors tested

Ratios $(R)$ were calculated by pairwise comparison of growth conditions: human plasma vs rich medium (HP:LB), mid-exponential phase vs stationary phase (expo:stat), and 37 vs $28{ }^{\circ} \mathrm{C}(37: 28)$. Absence of a value indicates that the difference was not significant $(P \geqslant 0.05)$.

\begin{tabular}{|c|c|c|c|c|c|}
\hline Gene ID & Name & Function & $R(\mathrm{HP}: \mathrm{LB})$ & $R$ (expo: stat) & $R(37: 28)$ \\
\hline & & Ybt siderophore iron-transport system & & & \\
\hline YPO1906 & psn & Pesticin/yersiniabactin receptor protein & 2.5 & & 2 \\
\hline YPO1907 & $y b t E$ & Yersiniabactin siderophore biosynthetic protein & 2 & & 1.5 \\
\hline YPO1908 & $y b t T$ & Yersiniabactin biosynthetic protein YbtT & 3 & & \\
\hline YPO1909 & $y b t U$ & Yersiniabactin biosynthetic protein $\mathrm{YbtU}$ & 2.9 & & 1.8 \\
\hline YPO1910 & $\operatorname{irpl}$ & Yersiniabactin biosynthetic protein & & & 1.7 \\
\hline YPO1911 & $\operatorname{irp} 2$ & Yersiniabactin biosynthetic protein & 7.1 & -1.4 & 2.5 \\
\hline YPO1912 & $y b t A$ & Transcriptional regulator YbtA & & -1.7 & 1.5 \\
\hline YPO1913 & $y b t P$ & Inner-membrane lipoprotein $\mathrm{ABC}$ transporter & 4 & & \\
\hline YPO1914 & $y b t Q$ & Inner-membrane $\mathrm{ABC}$ transporter $\mathrm{YbtQ}$ & 1.8 & & \\
\hline YPO1915 & $y b t X$ & Putative signal transducer & 2.9 & & 2.1 \\
\hline \multirow[t]{2}{*}{ YPO1916 } & $y b t S$ & Putative salicylate synthetase & 4.2 & & 2.3 \\
\hline & & ExbBD-TonB inner-membrane complex & & & \\
\hline YPO0682 & $\operatorname{exbB}$ & TonB-mediated protein & 3 & & \\
\hline YPO0683 & $\operatorname{exbD}$ & TonB-mediated protein & 3.6 & 2.5 & \\
\hline \multirow[t]{2}{*}{ YPO2193 } & $\operatorname{ton} B$ & Energy transducer and iron-uptake-related protein & 2.6 & & 1.9 \\
\hline & & Putative Ysu siderophore iron-transport system & & & \\
\hline YPO1528 & $y s u F$ & Putative ferric iron reductase & 3.1 & 1.7 & \\
\hline YPO1529 & $y s u J$ & Putative decarboxylase & & 1.8 & \\
\hline YPO1530 & alcA/ysuI & Putative siderophore biosynthetic enzyme & & & -1.8 \\
\hline YPO1532 & $y s u G$ & Putative siderophore biosynthetic enzyme & 1.8 & 1.5 & \\
\hline YPO1536 & ysuA & Putative periplasmic binding protein & 2.2 & & \\
\hline YPO1537 & $y s u R$ & Putative iron-siderophore receptor & 3.3 & & \\
\hline \multirow[t]{2}{*}{ YPO1538 } & $y s u E$ & Putative siderophore biosynthetic enzyme & 6.1 & 2.5 & \\
\hline & & Yfe iron $\mathrm{ABC}$ transporter & & & \\
\hline YPO2439 & $y f e A$ & Solute-binding protein & 10.2 & & \\
\hline YPO2440 & $y f e B$ & ATP-binding transport protein & 2.8 & & \\
\hline YPO2441 & $y f e C$ & Chelated iron transport system membrane protein & 1.8 & 1.8 & \\
\hline \multirow[t]{2}{*}{ YPO2445 } & $y f e E$ & Internal membrane protein & 2.1 & & \\
\hline & & Yiu iron $\mathrm{ABC}$ transporter & & & \\
\hline YPO1310 & уіuА & Putative periplasmic solute-binding protein & 1.7 & 2.1 & \\
\hline YPO1312 & yiu & Putative ATP-binding subunit & 2 & & \\
\hline \multirow[t]{2}{*}{ YPO1313 } & yiuR & Putative outer-membrane protein & 1.5 & & \\
\hline & & $\mathrm{Sfu} / \mathrm{Yfu}$ iron $\mathrm{ABC}$ transporter & & & \\
\hline YPO2958 & $s f u A / y f u A$ & Iron(III)-binding periplasmic protein & 3 & 1.7 & \\
\hline \multirow[t]{2}{*}{ YPO2960 } & $s f u C / y f u C$ & Iron(III)-transport ATP-binding protein & 1.8 & & \\
\hline & & Putative Fit iron $\mathrm{ABC}$ transporter & & & \\
\hline YPO4022 & & Putative iron-transport protein & 2.2 & 1.9 & \\
\hline YPO4023 & & Putative iron-transport permease & & 1.9 & \\
\hline \multirow[t]{2}{*}{ YPO4025 } & & Putative ATP-binding protein & 1.4 & 1.6 & \\
\hline & & Hmu haem transporter & & & \\
\hline YPO0279 & $h m u V$ & Haemin-transport system ATP-binding protein & 1.5 & & \\
\hline YPO0281 & hmuT & Haemin-binding periplasmic protein & 2.1 & & \\
\hline YPO0282 & hmuS & Haemin-transport protein & 2 & & \\
\hline \multirow[t]{2}{*}{ YPO0283 } & $h m u R$ & Haemin receptor precursor & 2 & & \\
\hline & & Has haemophore system & & & \\
\hline YPO3922 & hasA & Haemophore HasA & 1.8 & & \\
\hline \multirow[t]{2}{*}{ YPO0663 } & hasF & $\mathrm{ABC}$ transporter outer-membrane component & & 2.1 & \\
\hline & & Feo ferrous iron transporter & & & \\
\hline \multirow[t]{2}{*}{ YPO0131 } & feoC & Putative ferrous iron transport protein $\mathrm{C}$ & 2 & & -1.9 \\
\hline & & Ferric hydroxamate iron-transport systems & & & \\
\hline YPO0989 & $i u c A^{*}$ & Putative siderophore biosynthesis protein IucA & 2.1 & & \\
\hline YPO0993 & $i u c D$ & Putative siderophore biosynthesis protein IucD & -1.6 & & \\
\hline YPO1753 & $f c u A$ & Ferrichrome receptor protein & 1.7 & 1.5 & \\
\hline
\end{tabular}


Table 1. cont.

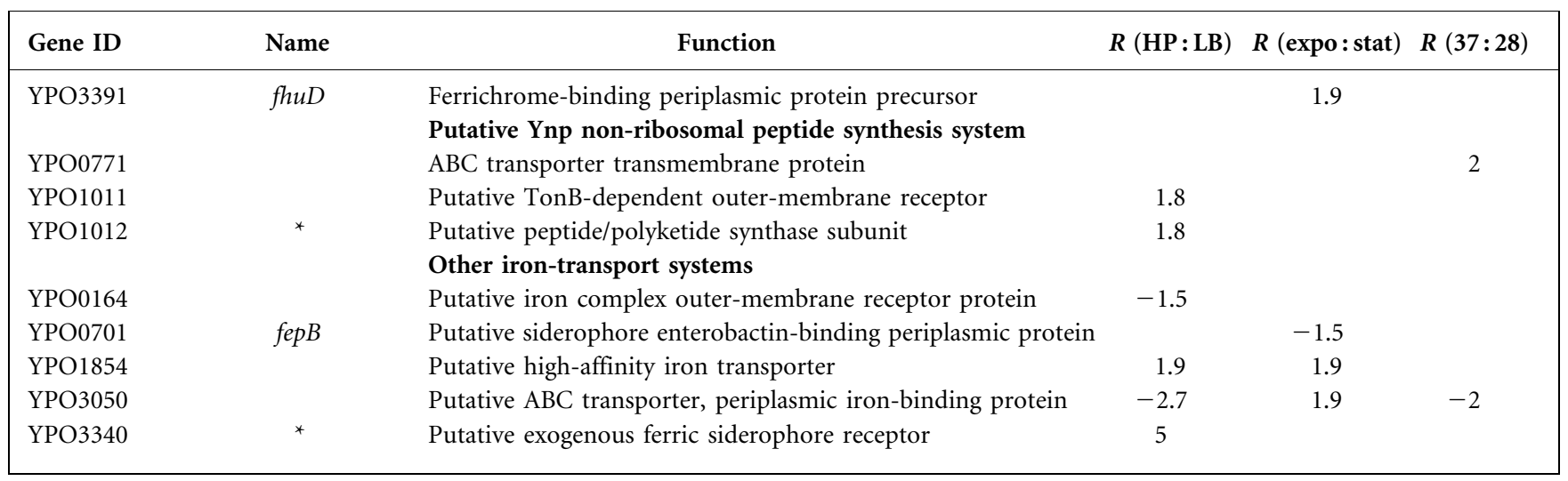

${ }^{\star}$ Pseudogene.

indeed produced and may thus participate in iron uptake in plasma. In addition to the siderophores, the $Y$. pestis chromosome also harbours several gene clusters encoding $\mathrm{ABC}$ transporters for inorganic iron uptake (Perry \& Fetherston, 2004). The $y f e A$ gene (encoding the solutebinding protein of the Yfe iron $\mathrm{ABC}$ transporter) was the most strongly upregulated gene (10.2-fold) in human plasma for the entire genome (Table 1, Supplementary Table S1). All other $y f e$ genes were also induced in human plasma (Table 1), suggesting that the Yfe iron-acquisition function plays a role during the septicaemic phase of plague. This correlates with the observation that in a Ybt defective strain, the Yfe system is essential for virulence when $Y$. pestis is intravenously injected into mice (Bearden \& Perry, 1999). Transcription of the $y f e A B C E$ genes was similar at 28 and $37{ }^{\circ} \mathrm{C}(P>0.5)$, indicating that these genes were not temperature-regulated. Growth in human plasma also stimulated transcription of genes encoding two other ABC iron transporters, the Yiu and Sfu/Yfu systems (Table 1). Both systems are known to be functional in Y. pestis (Kirillina et al., 2006). However, iron uptake by the Yfu or Yiu system was observed only when the Ybt-Yfe and Ybt-Yfe-Yfu systems, respectively, were mutated. Iron can also be acquired from an organic source such as haem and haem-containing proteins. In $Y$. pestis, transcription of the hmuVTSR genes (encoding the Hmu haem transporter) was induced in human plasma (Table 1). This fits with the observation that Hmumediated iron uptake is functional in Y. pestis (Hornung et al., 1996). Although the iron-acquisition function of the other five systems is putative, their transcriptional induction in human plasma suggests that they are synthesized and that they participate in iron uptake.

Eleven genes involved in the synthesis of surface structures were induced in human plasma (Fig. 1). The PsaA fimbria (also known as pH 6 antigen) is encoded by the psaABCEF cluster. Growth in human plasma upregulated transcription of $p s a E$ and psaF (Supplementary Table S1), suggesting a role for Psa in the septicaemic phase of plague. Indeed, mutation of $p s a E$ or $p s a A$ attenuates $Y$. pestis virulence after intravenous infection of mice (Lindler et al., 1990). Eight other gene clusters encoding putative fimbrial structures have been identified on the $Y$. pestis chromosome (Parkhill et al., 2001). Genes involved in the synthesis of four of these (YPO0698-0700, YPO1695-1700, YPO1918-1925 and YPO2940-2945) were induced in human plasma (Supplementary Table S1). Taken as a whole, our results indicate that these four fimbrial structures may (like Psa) exert a function during plague septicaemia.

\section{Genes which are transcriptionally induced in human plasma at $37^{\circ} \mathrm{C}$}

In order to identify the genes which are most likely to play a role in the septicaemic phase of plague, we focused our analysis on those induced both in human plasma and at $37^{\circ} \mathrm{C}$. In addition to the seven genes involved in yersiniabactin synthesis and transport (Table 1), 23 other genes were induced under the specified conditions (Table 2). Almost half of these [including YPO1649 and YPO3527, which were respectively the fourth and fifth most highly expressed genes in human plasma (Supplementary Table S4)] encoded proteins of unknown function. The hypothetical protein encoded by YPO1516 may have a general role in plague, since it was induced not only in human plasma at $37{ }^{\circ} \mathrm{C}$ but also in vivo during bubonic plague in rats and during pneumonic plague in mice (Lathem et al., 2005; Sebbane et al., 2006b).

Two genes known to participate in $Y$. pestis virulence $(s y c H$ and virG) were induced in human plasma and at $37{ }^{\circ} \mathrm{C}$ (Table 2). Both genes are borne on the $\mathrm{pCD} 1$ plasmid, which is essential for virulence in the three pathogenic Yersinia species (Y. pestis, Yersinia pseudotuberculosis and Yersinia enterocolitica) by mediating resistance to the host innate immune system (Marenne et al., 2004). This virulence results from the injection of Yop effector proteins into host cells by a 
type III secretion system called Ysc. Our transcriptome analysis showed that, in contrast to $\mathrm{sycH}$ and $\mathrm{virG}$, the pCD1borne genes lcrG, yadA, yopBDMT and yscBGHIJLNOPUY were constitutively expressed in human plasma and LB. In addition, 45 (including the $y s c-y o p$ virulon) out of the 57 pCD1 genes spotted on the macroarrays were induced at $37^{\circ} \mathrm{C}$ (Supplementary Table S2). A similar result has been observed in $Y$. pestis strain KIM5 D27 (biovar Medievalis) and strain 201 (biovar Microtus) (Han et al., 2004; Motin et al., 2004), which is consistent with the induction of Yop secretion on shifting from 26 to $37{ }^{\circ} \mathrm{C}$ in a calcium-free medium (Marenne et al., 2004).

Lastly, nine genes encoding metabolic functions were induced in human plasma at $37^{\circ} \mathrm{C}$ (Table 2). These metabolic functions include: intracellular sulphur oxidation (YPO0198 and YPO0199), biosynthesis of iron-sulphur proteins (YPO2404 of the HesB family), vitamin synthesis (thiC and YPO1603), carbohydrate metabolism ( $g \lg X$ and YPO3090) and nucleotide metabolism ( $n r d I)$. Interestingly, transcription of the other three genes composing the nrdHIEF ribonucleotide reductase operon was strongly induced (9-, 2.1- and 3.4-fold) in human plasma. Indeed, after $y f e A, n r d E$ and $n r d I$ exhibited the strongest upregulation values (Supplementary Table S1). Additionally, the $Y$. pestis nrdHIEF genes have also been found to be upregulated in the bubo during rat infection (Sebbane et al., 2006b). Together, these results suggest that purine/pyrimidine metabolism is essential for $Y$. pestis survival and/or growth in the mammalian host, and support the demonstration that purine metabolism is necessary for $Y$. pestis virulence (Munier-Lehmann et al., 2003).

\section{Growth-phase-dependent transcriptional regulation of genes induced in human plasma}

The physiological status of $Y$. pestis during infection is not known. A recent transcriptome analysis suggests that bacteria in the bubo are in a similar state to that observed during the stationary phase in vitro (Sebbane et al., 2006b). However, the bacteria proliferate rapidly during other stages of the infection process, which suggests that they are in an exponential growth phase. In order to identify the

Table 2. Genes not involved in iron acquisition and exhibiting transcriptional induction in human plasma at $37^{\circ} \mathrm{C}$

Ratios $(R)$ were calculated by pairwise comparison of growth conditions: human plasma vs rich medium (HP:LB), mid-exponential phase vs stationary phase (expo:stat), and 37 vs $28{ }^{\circ} \mathrm{C}(37: 28)$. Absence of a value indicates that the difference was not significant $(P \geqslant 0.05)$.

\begin{tabular}{|c|c|c|c|c|c|}
\hline Gene ID & Name & Function & $R(\mathrm{HP}: \mathrm{LB})$ & $R$ (expo: stat) & $R(37: 28)$ \\
\hline & & Involved in virulence & & & \\
\hline YPCD1.95c & $s y c H$ & Secretion chaperone for YopH & 2 & & 8.3 \\
\hline YPCD 1.48 & $\operatorname{virG}$ & $\begin{array}{l}\text { Yop secretion and targeting control lipoprotein } \\
\text { Involved in metabolism }\end{array}$ & 1.5 & & 3.3 \\
\hline YPO0198 & & Putative intracellular sulphur oxidation protein & 2.6 & -1.7 & 2.6 \\
\hline YPO0199 & & Putative intracellular sulphur oxidation protein & 1.8 & -1.4 & 1.7 \\
\hline YPO1462 & & Putative acyl carrier protein & 1.6 & & 1.5 \\
\hline YPO1603 & $p a b C$ & 4-Amino-4-deoxychorismate lyase & 1.8 & -1.4 & 1.4 \\
\hline YPO2404 & & Conserved hypothetical protein (HesB domain) & 3.1 & 2 & 1.7 \\
\hline YPO2650 & $n r d I$ & NrdI protein homologue & 8.8 & & 2 \\
\hline YPO3090 & $u \operatorname{sh} A^{*}$ & UDP-sugar hydrolase & 1.8 & -1.5 & 1.7 \\
\hline YPO3739 & thiC & Thiamine biosynthesis protein ThiC & 2 & & 2 \\
\hline YPO3941 & $\operatorname{glg} X$ & $\begin{array}{l}\text { Putative } \alpha \text {-amylase } \\
\text { Miscellaneous }\end{array}$ & 1.6 & & 1.7 \\
\hline YPO4051 & $\operatorname{tnp} A$ & $\begin{array}{l}\text { Transposase (partial) } \\
\text { Unknown }\end{array}$ & 1.4 & & 1.7 \\
\hline YPO0445 & & Conserved hypothetical protein & 1.4 & & 1.5 \\
\hline YPO1516 & & Hypothetical protein & 1.7 & & 1.5 \\
\hline YPO1649 & & Hypothetical protein & 2.7 & & 1.8 \\
\hline YPO2276A & & Putative phage-related membrane protein & 1.4 & & 1.7 \\
\hline YPO2605 & & Conserved hypothetical protein & 1.4 & & 1.5 \\
\hline YPO2606 & & Conserved hypothetical protein & 2.7 & -1.6 & 2 \\
\hline YPO2700 & & Conserved hypothetical protein & 1.5 & & 1.5 \\
\hline YPO3518 & & Conserved putative exported protein & 2.2 & & 2.1 \\
\hline YPO3527 & & Conserved hypothetical protein & 3.6 & -5.1 & 1.6 \\
\hline YPO4064 & & Hypothetical protein & 2.7 & & 2 \\
\hline YPO4086 & & Putative lipoprotein & 1.8 & & 2.4 \\
\hline
\end{tabular}

${ }^{\star}$ Pseudogene. 
Table 3. Genes showing transcriptional induction in human plasma during exponential phase

Ratios $(R)$ were calculated by pairwise comparison of growth conditions: human plasma vs rich medium (HP:LB), mid-exponential phase vs stationary phase (expo:stat), and 37 vs $28{ }^{\circ} \mathrm{C}(37: 28)$. Absence of a value indicates that the difference was not significant $(P \geqslant 0.05)$.

\begin{tabular}{|c|c|c|c|c|c|}
\hline Gene ID & Name & Function & $R(\mathrm{HP}: \mathrm{LB})$ & $R$ (expo: stat) & $R(37: 28)$ \\
\hline & & Iron metabolism & & & \\
\hline YPO0683 & $\operatorname{exbD}$ & TonB-mediated protein & 3.6 & 2.5 & \\
\hline YPO1528 & $y s u F$ & Putative ferric iron reductase & 3.1 & 1.7 & \\
\hline YPO1532 & $y s u G$ & Putative siderophore biosynthetic enzyme & 1.8 & 1.5 & \\
\hline YPO1538 & $y s u E$ & Putative siderophore biosynthetic enzyme & 6.1 & 2.5 & \\
\hline YPO1854 & & Putative high-affinity iron transporter & 1.9 & 1.9 & \\
\hline YPO2441 & $y f e C$ & Chelated iron transport system membrane protein & 1.8 & 1.8 & \\
\hline YPO2958 & $s f u A / y f u A$ & Iron(III)-binding periplasmic protein & 3 & 1.7 & \\
\hline YPO4022 & & Putative iron-transport protein & 2.2 & 1.9 & \\
\hline YPO4025 & & $\begin{array}{l}\text { Putative iron ABC transporter, ATP-binding protein } \\
\text { Stress-responsive proteins }\end{array}$ & 1.4 & 1.6 & \\
\hline YPO1133 & gpmA & Phosphoglycerate mutase 1 & 3.7 & 3.1 & \\
\hline YPO1608 & $p t s G$ & $\begin{array}{l}\text { Phosphotransferase system (PTS), glucose-specific IIBC } \\
\text { component }\end{array}$ & 1.7 & 1.7 & \\
\hline YPO1758 & $\operatorname{man} X$ & PTS, mannose-specific IIAB component & 3.2 & 1.8 & \\
\hline YPO2994 & ptsI & PTS, enzyme I component & 1.4 & 2.1 & \\
\hline \multirow{2}{*}{ YPO3718 } & $p g i$ & Glucose-6-phosphate isomerase & 1.5 & 1.7 & \\
\hline & & Amino acid metabolism & & & \\
\hline YPO0914 & $\operatorname{ser} A$ & D-3-Phosphoglycerate dehydrogenase & 1.5 & 1.7 & \\
\hline YPO1193 & & Putative pyridoxal-dependent decarboxylase & 1.7 & 1.5 & -1.8 \\
\hline YPO3727 & metA & Homoserine $O$-succinyltransferase & 1.5 & 1.8 & \\
\hline YPO1684 & * & Putative surface protein & 2.1 & 4.1 & -2.6 \\
\hline YPO1967 & $n m p C / p h m A^{*}$ & Outer-membrane protein & 1.8 & 1.7 & \\
\hline \multirow[t]{2}{*}{ YPO2394 } & $l p p$ & Major outer-membrane lipoprotein & 2 & 4 & \\
\hline & & Regulator & & & \\
\hline \multirow[t]{2}{*}{ YPO3545 } & & LysR-family transcriptional regulatory protein & 1.7 & 1.4 & \\
\hline & & Miscellaneous & & & \\
\hline YPO0027 & & Putative phosphatase & 1.8 & 5.5 & -3.1 \\
\hline YPO2180 & $a d h E$ & Aldehyde-alcohol dehydrogenase & 3.4 & 1.6 & \\
\hline YPO2367 & gst & Glutathione $S$-transferase & 2.1 & 1.8 & \\
\hline YPO2404 & & Conserved hypothetical protein (HesB domain) & 3.1 & 2 & 1.7 \\
\hline YPO3300 & $\operatorname{luxS}$ & Autoinducer-2 production protein & 1.9 & 2.6 & -1.9 \\
\hline \multirow[t]{2}{*}{ YPO3223 } & $\mathrm{crl}$ & Curlin genes regulatory protein & 1.6 & 3.2 & -1.6 \\
\hline & & IS element & & & \\
\hline \multirow[t]{2}{*}{$\dagger$} & & Transposase for insertion sequence IS1661 & 1.5 & 2.1 & \\
\hline & & Unknown & & & \\
\hline YPO0100 & & Hypothetical protein & 1.9 & 3 & -2.2 \\
\hline YPO0102 & & Putative exported protein & 1.8 & 4.2 & -3.2 \\
\hline YPO0337 & & Putative exported protein & 2 & 1.5 & \\
\hline YPO0457 & $\operatorname{creA}$ & Putative exported (periplasmic) protein & 2.3 & 3.7 & -2.3 \\
\hline
\end{tabular}


Table 3. cont.

\begin{tabular}{|c|c|c|c|c|c|}
\hline Gene ID & Name & Function & $R(\mathrm{HP}: \mathrm{LB})$ & $R$ (expo: stat) & $R(37: 28)$ \\
\hline YPO0498 & & Hypothetical protein & 3.7 & 13.9 & -8.8 \\
\hline YPO0499 & & Hypothetical protein & 2.4 & 14.3 & -12.7 \\
\hline YPO0500 & & Conserved hypothetical protein & 2.3 & 12.2 & -8.2 \\
\hline YPO0502 & & Conserved hypothetical protein & 1.9 & 20.2 & -36.9 \\
\hline YPO0510 & & Hypothetical protein & 1.5 & 2.8 & -2.4 \\
\hline YPO0511 & & Hypothetical protein & 1.5 & 1.7 & \\
\hline YPO0657 & & Hypothetical protein & 2 & 4 & \\
\hline YPO1243 & & Hypothetical protein & 1.8 & 1.7 & -1.9 \\
\hline YPO1527 & & Putative membrane protein & 1.4 & 1.6 & -1.6 \\
\hline YPO1588 & & Conserved hypothetical protein & 2.1 & 1.5 & -1.8 \\
\hline YPO2226 & & Hypothetical protein & 1.8 & 2 & -1.6 \\
\hline YPO2531 & elaB & Putative membrane protein & 3.7 & 2 & -1.6 \\
\hline YPO3336 & & Conserved hypothetical protein & 4.7 & 1.4 & \\
\hline YPO3522 & & Conserved hypothetical protein & 1.5 & 1.9 & \\
\hline YPO3534 & & Putative exported protein & 1.9 & 2.2 & \\
\hline YPO4070 & yiaF & Putative exported protein & 1.7 & 8.9 & -3.8 \\
\hline
\end{tabular}

${ }^{\star}$ Pseudogene.

†YPO0118, YPO0756, YPO0997, YPO3491, YPO3703, YPO3932, YPO4047, YPO4092

genes specifically expressed in each growth phase, we compared the transcriptional profiles of $Y$. pestis harvested during the exponential and stationary phases in human plasma.

Genes showing transcriptional induction in human plasma during the exponential phase. Fifty-eight genes induced in human plasma were upregulated during the exponential phase (Table 3). The most represented functional category ( 20 genes) was that corresponding to unknown functions, followed by genes involved in iron metabolism (11 genes).

The outer-membrane lipoprotein-encoding gene $l p p$ was the third most highly expressed gene during growth of $Y$. pestis in human plasma (Supplementary Table S4). A proteome analysis showed that Lpp is highly immunogenic upon Y. pestis EV76 injection into rabbits (Li et al., 2005). Therefore, Lpp may represent a major constituent of the $Y$. pestis membrane, and may be important at various steps of the disease. In fact, virulence of Salmonella enterica is abolished by mutating one or the other of the two copies of the lpp gene (Sha et al., 2004).

Genes showing transcriptional induction in human plasma during the stationary phase. Fifty-nine genes induced in human plasma were upregulated during the stationary phase (Table 4). Genes encoding proteins of unknown function were the most numerous (26). Of these, YPO1994 had been previously identified by a signaturetagged mutagenesis (STM) screen following subcutaneous infection of mice with $Y$. pestis Kimberley53 (Flashner et al., 2004). The YPO1994 mutation did not affect mouse mortality but decreased the capacity of the bacterium to colonize the spleen. YPO2976 (which encodes another hypothetical protein of unknown function) has been shown to be induced in vivo in the rat bubo (Sebbane et al., 2006b) and in the mouse lung (Lathem et al., 2005; Sebbane et al., 2006b), suggesting that this gene is important in all stages of the infection process.

While several iron-uptake genes were induced during the exponential growth phase in human plasma (Table 3), three genes, znuA, mntH and YPO2332, involved in zinc, manganese and magnesium uptake, respectively, were specifically induced during the stationary phase (Table 4). Transcription of $z n u A$ has also been shown to be induced in vivo during bubonic and pneumonic murine plague (Lathem et al., 2005; Sebbane et al., 2006b), suggesting that this zinc-uptake system may be essential for $Y$. pestis at various stages of the disease. A role in virulence has been demonstrated for other pathogens, such as S. enterica, Pasteurella multocida and Brucella abortus (Campoy et al., 2002; Garrido et al., 2003; Kim et al., 2004).

In contrast with the exponential-phase results, only two genes (irp2 and $b f r$ ) involved in iron metabolism were induced during the stationary phase (Table 4 ). The $b f r$ gene encodes bacterioferritin, which, in association with Bfd ferredoxin, is thought to release iron under iron-restriction conditions. Although the bfd gene was not significantly induced during the stationary phase, it was 3.2-fold induced in human plasma (Supplementary Table S1). This is in agreement with previous results showing that $b f r$ and $b f d$ are upregulated in $Y$. pestis biovar Microtus strain 201 during iron depletion (Zhou et al., 2006). 
Table 4. Genes exhibiting transcriptional induction in human plasma during the stationary phase

Ratios $(R)$ were calculated by pairwise comparison of growth conditions: human plasma vs rich medium (HP:LB), mid-exponential phase vs stationary phase (expo:stat), and 37 vs $28{ }^{\circ} \mathrm{C}(37: 28)$. Absence of a value indicates that the difference was not significant $(P \geqslant 0.05)$.

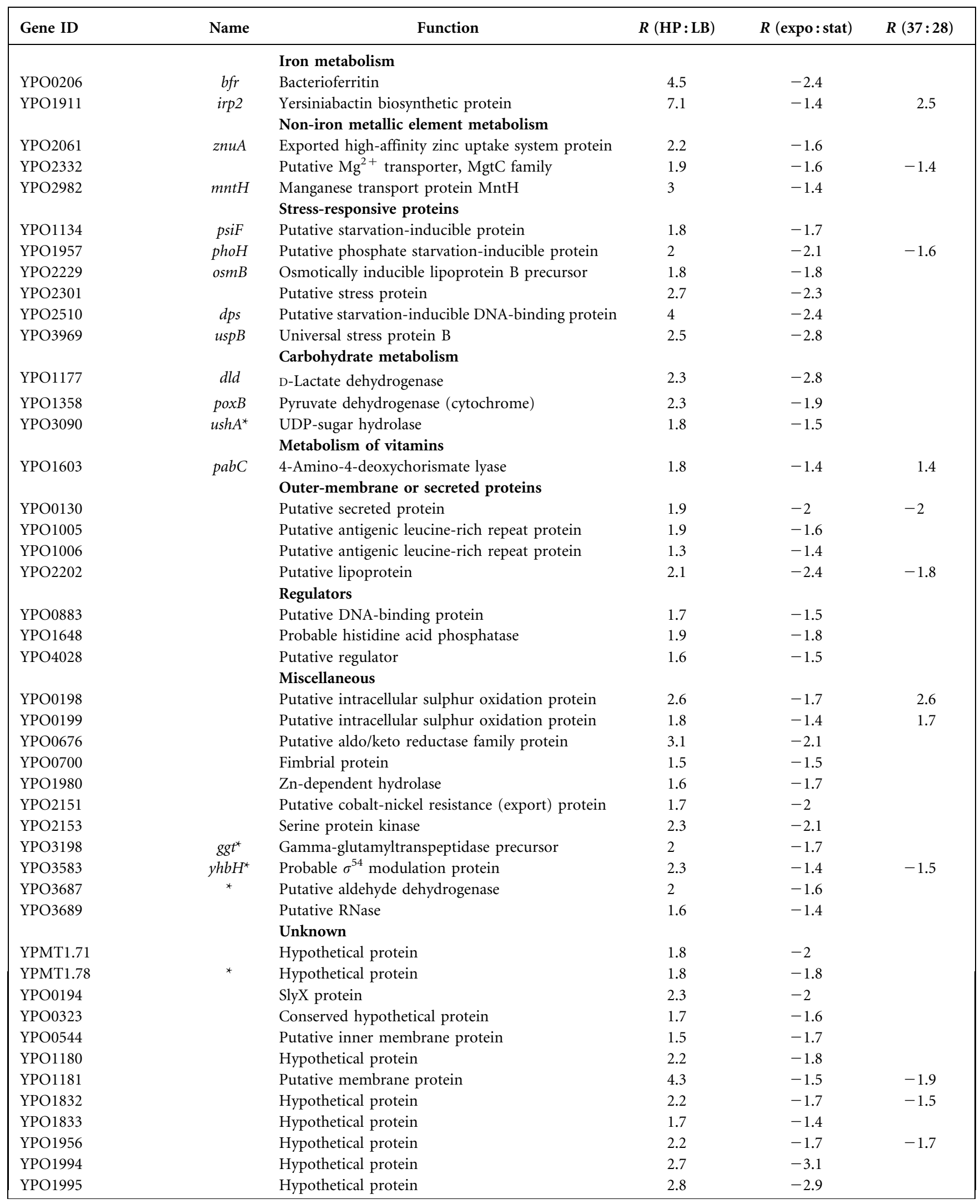


Table 4. cont.

\begin{tabular}{|c|c|c|c|c|c|}
\hline Gene ID & Name & Function & $R(\mathrm{HP}: \mathrm{LB})$ & $R$ (expo: stat) & $R(37: 28)$ \\
\hline YPO1996 & & Hypothetical protein & 2 & -2.4 & \\
\hline YPO2092 & & Hypothetical phage protein & 1.9 & -2.5 & \\
\hline YPO2152 & & Conserved hypothetical protein & 2 & -2.4 & \\
\hline YPO2362 & & Putative membrane protein & 1.9 & -1.8 & \\
\hline YPO2363 & & Conserved hypothetical protein & 1.4 & -1.7 & \\
\hline YPO2435 & & Putative membrane protein & 2 & -1.7 & \\
\hline YPO2606 & & Conserved hypothetical protein & 2.7 & -1.6 & 2 \\
\hline YPO2611 & & Conserved hypothetical protein & 1.6 & -1.6 & \\
\hline YPO2820 & & Hypothetical protein & 1.9 & -2.5 & \\
\hline YPO2854 & & Conserved hypothetical protein & 2 & -1.9 & -1.7 \\
\hline YPO2976 & & Conserved hypothetical protein & 2.6 & -3.1 & \\
\hline YPO2987 & & Putative exported protein & 1.7 & -1.6 & \\
\hline YPO3027 & $y g i W$ & Putative exported protein & 3.7 & -1.5 & -1.8 \\
\hline YPO3527 & & Conserved hypothetical protein & 3.6 & -5.1 & 1.6 \\
\hline
\end{tabular}

${ }^{\star}$ Pseudogene.

\section{Regulation of genes carried on the two Y. pestis- specific plasmids}

$Y$. pestis classically harbours three plasmids: the virulence plasmid pCD1 $(70.3 \mathrm{~kb})$, which is common to the three pathogenic Yersinia species, and two $Y$. pestis-specific plasmids, pMT1 $(96.2 \mathrm{~kb})$ and pPCP1 $(9.6 \mathrm{~kb})$. In order to investigate the role of these plasmids during the septicaemic phase of plague, we analysed the transcriptional regulation of pMT1- and pPCP1-borne genes. None of the three pPCP1 genes ( $p s t$, pim and pla) spotted on macroarrays was significantly induced in human plasma. Of the 69 pMT1 genes spotted on the macroarrays, only two (YPMT1.71 and the pseudogene YPMT1.78) were induced in human plasma (both 1.8-fold). YPMT1.71 encodes a hypothetical protein which generates an antibody response after rabbit immunization with $Y$. pestis EV76 (Chen et al., 2006). All caf genes (encoding the F1 capsular antigen) were induced at $37{ }^{\circ} \mathrm{C}$. The upregulation values of caf1 (41.5-fold) and caf1A (22.7-fold) were among the highest encountered in the whole genome. This strong temperature induction has also been observed in $Y$. pestis strains KIM5 D27 and 201, and agrees with the $37{ }^{\circ} \mathrm{C}$-inducible antiphagocytic property of the F1 capsular antigen (Du et al., 2002; Han et al., 2004; Motin et al., 2004). The ymt gene, encoding a phospholipase D which is not a virulence factor in mice but which is important for flea-borne transmission (Hinnebusch et al., 2000, 2002), was constitutively expressed in human plasma and LB.

In conclusion, a transcriptome approach was used for the identification of genes induced during growth of $Y$. pestis in human plasma. Several of the identified genes potentially represent new virulence factors active in the septicaemic phase of plague in humans. They may be important once the bacteria have reached the bloodstream, by ensuring $Y$. pestis survival during infection (protection against oxidative and other stresses, cell wall accommodation), by facilitating its proliferation (metabolic adaptation), or by damaging the host (adhesins, invasins and lytic enzymes such as proteases and phospholipases). Further characterization of these genes and their products may provide insight into the mechanisms responsible for the very high pathogenic potential of $Y$. pestis.

\section{ACKNOWLEDGEMENTS}

This work was supported in part by grant 0234021 from the 'Délégation Générale pour l'Armement' and grant PTR88 from the 'Programmes transversaux de recherche', Institut Pasteur.

\section{REFERENCES}

Achtman, M., Morelli, G., Zhu, P., Wirth, T., Diehl, I., Kusecek, B., Vogler, A. J., Wagner, D. M., Allender, C. J. \& other authors (2004). Microevolution and history of the plague bacillus, Yersinia pestis. Proc Natl Acad Sci U S A 101, 17837-17842.

Bearden, S. W. \& Perry, R. D. (1999). The Yfe system of Yersinia pestis transports iron and manganese and is required for full virulence of plague. Mol Microbiol 32, 403-414.

Bearden, S. W., Fetherston, J. D. \& Perry, R. D. (1997). Genetic organization of the yersiniabactin biosynthetic region and construction of avirulent mutants in Yersinia pestis. Infect Immun 65, 1659-1668.

Brubaker, R. R. (2000). Yersinia pestis and bubonic plague. In The Prokaryotes: an Evolving Electronic Resource for the Microbiological Community. Edited by M. Dworkin, S. Falkow, E. Rosenberg, K.-H. Schleifer \& E. Stackelbrandt. New York: Springer.

Campoy, S., Jara, M., Busquets, N., Perez De Rozas, A. M., Badiola, I. \& Barbe, J. (2002). Role of the high-affinity zinc uptake $z n u A B C$ system in Salmonella enterica serovar Typhimurium virulence. Infect Immun 70, 4721-4725.

Chen, Z., Li, B., Zhang, J., Qin, L., Zhou, D., Han, Y., Du, Z., Guo, Z., Song, Y. \& Yang, R. (2006). Quorum sensing affects virulenceassociated proteins F1, LcrV, KatY and pH6 etc. of Yersinia pestis as revealed by protein microarray-based antibody profiling. Microbes Infect 8, 2501-2508. 
Dennis, D. T., Gage, K. L., Gratz, N., Poland, J. D. \& Tikhomirov, E. (1999). Plague manual - epidemiology, distribution, surveillance and control. Geneva: World Health Organization.

Devignat, R. (1951). Variétés de l'espèce Pasteurella pestis. Nouvelle hypothèse. Bulletin de l'Organisation Mondiale de la Santé 4, 247-263.

Du, Y., Rosqvist, R. \& Forsberg, A. (2002). Role of fraction 1 antigen of Yersinia pestis in inhibition of phagocytosis. Infect Immun 70, 1453-1460.

Flashner, Y., Mamroud, E., Tidhar, A., Ber, R., Aftalion, M., Gur, D., Lazar, S., Zvi, A., Bino, T. \& other authors (2004). Generation of Yersinia pestis attenuated strains by signature-tagged mutagenesis in search of novel vaccine candidates. Infect Immun 72, 908-915.

Frangeul, L., Glaser, P., Rusniok, C., Buchrieser, C., Duchaud, E., Dehoux, P. \& Kunst, F. (2004). CAAT-Box, contigs-assembly and annotation tool-box for genome sequencing projects. Bioinformatics 20, 790-797.

Garrido, M. E., Bosch, M., Medina, R., Llagostera, M., Perez de Rozas, A. M., Badiola, I. \& Barbe, J. (2003). The high-affinity zinc-uptake system $z n u A C B$ is under control of the iron-uptake regulator (fur) gene in the animal pathogen Pasteurella multocida. FEMS Microbiol Lett 221, 31-37.

Han, Y., Zhou, D., Pang, X., Song, Y., Zhang, L., Bao, J., Tong, Z., Wang, J., Guo, Z. \& other authors (2004). Microarray analysis of temperature-induced transcriptome of Yersinia pestis. Microbiol Immunol 48, 791-805.

Hinnebusch, J., Cherepanov, P., Du, Y., Rudolph, A., Dixon, J. D., Schwan, T. \& Forsberg, A. (2000). Murine toxin of Yersinia pestis shows phospholipase D activity but is not required for virulence in mice. Int J Med Microbiol 290, 483-487.

Hinnebusch, B. J., Rudolph, A. E., Cherepanov, P., Dixon, J. E., Schwan, T. G. \& Forsberg, A. (2002). Role of Yersinia murine toxin in survival of Yersinia pestis in the midgut of the flea vector. Science 296, 733-735.

Hornung, J. M., Jones, H. A. \& Perry, R. D. (1996). The hmu locus of Yersinia pestis is essential for utilization of free haemin and haemprotein complexes as iron sources. Mol Microbiol 20, 725-739.

Kim, S., Watanabe, K., Shirahata, T. \& Watarai, M. (2004). Zinc uptake system (znuA locus) of Brucella abortus is essential for intracellular survival and virulence in mice. $J$ Vet Med Sci 66, 1059-1063.

Kirillina, O., Bobrov, A. G., Fetherston, J. D. \& Perry, R. D. (2006). Hierarchy of iron uptake systems: Yfu and Yiu are functional in Yersinia pestis. Infect Immun 74, 6171-6178.

Lathem, W. W., Crosby, S. D., Miller, V. L. \& Goldman, W. E. (2005). Progression of primary pneumonic plague: a mouse model of infection, pathology and bacterial transcriptional activity. Proc Natl Acad Sci U S A 102, 17786-17791.

Li, B., Jiang, L., Song, Q., Yang, J., Chen, Z., Guo, Z., Zhou, D., Du, Z., Song, Y. \& other authors (2005). Protein microarray for profiling antibody responses to Yersinia pestis live vaccine. Infect Immun 73, 3734-3739.

Lindler, L. E., Klempner, M. S. \& Straley, S. C. (1990). Yersinia pestis pH 6 antigen: genetic, biochemical and virulence characterization of a protein involved in the pathogenesis of bubonic plague. Infect Immun 58, 2569-2577.
Marenne, M.-N., Mota, L. J. \& Cornelis, G. R. (2004). The pYV plasmid and the Ysc-Yop type III secretion system. In Yersinia Molecular and Cellular Biology, pp. 319-348. Edited by E. Carniel \& B. J. Hinnebusch. Wymondham, UK: Horizon Bioscience.

Motin, V. L., Georgescu, A. M., Fitch, J. P., Gu, P. P., Nelson, D. O., Mabery, S. L., Garnham, J. B., Sokhansanj, B. A., Ott, L. L. \& other authors (2004). Temporal global changes in gene expression during temperature transition in Yersinia pestis. J Bacteriol 186, 6298-6305.

Munier-Lehmann, H., Chenal-Francisque, V., Ionescu, M., Chrisova, P., Foulon, J., Carniel, E. \& Barzu, O. (2003). Relationship between bacterial virulence and nucleotide metabolism: a mutation in the adenylate kinase gene renders Yersinia pestis avirulent. Biochem J 373, 515-522.

Parkhill, J., Wren, B. W., Thomson, N. R., Titball, R. W., Holden, M. T., Prentice, M. B., Sebaihia, M., James, K. D., Churcher, C. \& other authors (2001). Genome sequence of Yersinia pestis, the causative agent of plague. Nature 413, 523-527.

Perry, R. D. \& Fetherston, J. (2004). Iron and heme uptake systems. In Yersinia Molecular and Cellular Biology, pp. 257-283. Edited by E. Carniel \& B. J. Hinnebusch. Wymondham, UK: Horizon Bioscience.

Perry, R. D., Shah, J., Bearden, S. W., Thompson, J. M. \& Fetherston, J. D. (2003). Yersinia pestis TonB: role in iron, heme and hemoprotein utilization. Infect Immun 71, 4159-4162.

Porat, R., McCabe, W. R. \& Brubaker, R. R. (1995). Lipopolysaccharide-associated resistance to killing of Yersinia by complement. J Endotoxin Res 2, 91-97.

Sebbane, F., Jarrett, C. O., Gardner, D., Long, D. \& Hinnebusch, B. J. (2006a). Role of the Yersinia pestis plasminogen activator in the incidence of distinct septicemic and bubonic forms of flea-borne plague. Proc Natl Acad Sci U S A 103, 5526-5530.

Sebbane, F., Lemaitre, N., Sturdevant, D. E., Rebeil, R., Virtaneva, K., Porcella, S. F. \& Hinnebusch, B. J. (2006b). Adaptive response of Yersinia pestis to extracellular effectors of innate immunity during bubonic plague. Proc Natl Acad Sci U S A 103, 11766-11771.

Sha, J., Fadl, A. A., Klimpel, G. R., Niesel, D. W., Popov, V. L. \& Chopra, A. K. (2004). The two murein lipoproteins of Salmonella enterica serovar Typhimurium contribute to the virulence of the organism. Infect Immun 72, 3987-4003.

Sodeinde, O. A., Subrahmanyam, Y. V., Stark, K., Quan, T., Bao, Y. \& Goguen, J. D. (1992). A surface protease and the invasive character of plague. Science 258, 1004-1007.

Stanier, R. Y., Ingraham, J. L., Wheelis, M. L. \& Painter, P. R. (1986). The Microbial World, 5th edn. Upper Saddle River, NJ: Prentice-Hall.

Une, T. \& Brubaker, R. R. (1984). In vivo comparison of avirulent Vwa- and Pgm- or Pst ${ }^{\mathrm{r}}$ phenotypes of Yersiniae. Infect Immun 43, 895-900.

Zhou, D., Tong, Z., Song, Y., Han, Y., Pei, D., Pang, X., Zhai, J., Li, M., Cui, B. \& other authors (2004). Genetics of metabolic variations between Yersinia pestis biovars and the proposal of a new biovar, microtus. J Bacteriol 186, 5147-5152.

Zhou, D., Qin, L., Han, Y., Qiu, J., Chen, Z., Li, B., Song, Y., Wang, J., Guo, Z. \& other authors (2006). Global analysis of iron assimilation and fur regulation in Yersinia pestis. FEMS Microbiol Lett 258, 9-17.

Edited by: T. Abee 